thyroid medullary carcinoma and who had in his serum $400 \mathrm{mg}$. of IgDL paraprotein. Bone marrow and radiological examination were negative. In co-operation with $\mathrm{Mr}$. Selwyn Taylor and Dr. E. D. Williams we could detect no arteriovenous difference in the plasma level of IgD across the circulation through a large mass of mediastinal carcinoma, some of which was successfully grown in tissue culture by Dr. P. J. L. Holt. Radioactive amino-acids were added, followed by carrier IgDL protein, but radioimmunoelectrophoresis did not show any IgD synthesis by the thyroid medullary carcinoma. It would thus seem that IgD, like other paraproteins, can sometimes have benign significance.

This work has been a by-product of the M.R.C. myeloma trial. I am grateful to all the participants (see Hobbs, 1969) and those colleagues mentioned in Table I and the text who have helped in the study of the patients. I am also indebted to Miss Felicity Henderson and Mrs. Urmila Patel for their assistance and to Professors I. D. P. Wootton and J. V. Dacie, and Dr. D. Galton for their encouragement.
REFERENCES

Axelsson, U. (1966). Scand. F. Haemat., 3, 123.

Bachmann, R. (1965). Acta med. scand., 178, 801.

Ben-Bassat, I., Frand, U. I., Isersky, C., and Ramot, B. (1968). Arch. intern. Med., 121, 361 .

Bert, G., and Fontana, F. (1968). Brit. med. F., 2, 117

Burtin, P., Guilbert, B., and Buffe, D. (1966). Clin. chim. Acta, 13, 675.

Dammacco, F., and Bonomo, L. (1968). Scand. F. Haemat., 5, 161.

Edwards, G. A., and Zawadzki, Z. A. (1967). Amer. F. Med., 43, 194.

Hobbs, J. R. (1968). Brit. F. Cancer. In press.

Hobbs, J. R. (1969). Brit. 手. Haemat. In press.

Hobbs, J. R., et al. (1966). Lancet, 2, 614 .

Innes, J., R., et Newall, J. (1961). Lancet, i, 239.

Klemm, D., Schubothe, H., Heimpel, H., and Kasemir, H. D. (1967). Klin. W Schr., 45, 590 .

Masaki, A., Danbara, C., Teramura, F., Sanada, I., Takata, T., and Shinozaki, K. (1967).' Acta haemat. jap., 30, 475 .

Rogentine, G. N., Rowe, D. S., Bradley, J., Waldmann, T. A., and Fahey, J. L." (1966).' F. clin.' Invest., 45,"1467.

Rowe, D. S., and Fahey, J. L. (1965). भ. exp. Med., 121, 171.

Spengler, G. A., Bütler, R., Pflugshaupt, R., Lopez, V., and Barandun, S. (1967). Schweiz. med. W schr., 97,170

Ventruto, V., and Quattrin, N. (1966). Haematologica, 51, 545.

Wiedermann, D., Wiedermann, B., Rádl, J., Skvařil, F., and Vacrman, J. P (1967), Schweiz, med. Wschr, 97, 207.

Zawadzki, Z. A., and Edwards, G. A. (1967). Amer. F. clin. Path., 48, 418

Zawadzki, Z. A., and Rubini, J. R. (1967). Arch. in:ern. Med., 119, 397.

\title{
Hypermagnesaemia in Presence of Magnesium Depletion in Acute-on-chronic Renal Failure
}

\author{
P. LIM,* M.B., B.CHIR., M.R.C.P. ; O. T. KHOO, $†$ M.D., F.R.C.P.ED., F.R.C.P.GLASG.
}

\begin{abstract}
Summary : A patient with renal failure developed hypermagnesaemia, with confusion, drowsiness, and dysarthria. Nevertheless, the dietary magnesium content was low, and investigation showed actual intracellular depletion of magnesium. The cause of this state is not known, though it is presumably connected with a failure to maintain the normal concentration gradient of magnesium across the cell wall. The clinical state and the serum magnesium level returned to normal after treatment with calcium gluconate.
\end{abstract}

\section{Introduction}

In renal failure hypermagnesaemia of ten develops in association with oliguric crisis (Hamburger, 1957 ; Takayasu et al., 1962). Severe reduction of glomerular filtration rate to less than 30 $\mathrm{ml} . / \mathrm{min}$. (Robinson et al., 1959), increased tissue catabolism and acidosis leading to shift of intracellular magnesium to the extracellular fluid (Nabarro et al., 1952; Martin and Jones, 1961), and the intake of magnesium-containing medication (Smith and Hammarsten, 1958) are responsible factors, jointly or severally. Very high values, in excess of $4 \mathrm{mEq} / 1$., are usually associated with a large intake of magnesium in the oliguric phase (Randall et al., 1964).

The case reported here is one of acute-on-chronic renal failure where the patient developed very high serum magnesium while on a restricted protein diet of low magnesium content. Magnesium-containing drugs were not given. A very interesting feature is the evidence of magnesium depletion while the patient was hypermagnesaemic.

* Lecturer, Clinical Medicine.

† Professor of Clinical Medicine.

University of Singapore, Singapore 3.

\section{Case Report}

A 57-year-old man, a known acromegalic, was admitted to the General Hospital, Singapore, on 4 August 1967. He gave a history of recurrent attacks of fever and chill associated with frequency of micturition, lethargy, and anorexia for one year, and a dull constant pain in the left loin associated with dysuria for three days. There had been no other past illness of note.

On examination, in addition to features of acromegaly (large protruding lower jaw, " main succulente," large tongue, thick coarse skin with multiple lipomata, and hepatomegaly) he was anaemic and sallow. An early diastolic murmur was heard at the left parasternal edge in the fourth and fifth intercostal spaces. There was collapsing pulse. Blood pressure was 130/60 and the left ventricle was enlarged. There was no evidence of congestive heart failure, and no tenderness in the left loin. The kidneys were not palpable. No abnormality was found in the respiratory and neurological systems. Fundi and visual fields were normal.

Serological tests for syphilis were negative. Blood urea was 240 mg. $/ 100 \mathrm{ml}$; creatinine clearance $1.6 \mathrm{ml} . / \mathrm{min}$.; $\mathrm{K} 5.8 \mathrm{mEq} / \mathrm{l}$.; $\mathrm{Mg} 2.9 \mathrm{mEq} / 1$. (normal $2.0 \pm 0.34$ (2 S.D.) $\mathrm{mEq} / \mathrm{l}$.) ; Ca $8.5 \mathrm{mg}$.) $100 \mathrm{ml}$. (normal $9.5 \pm 0.8 \mathrm{mg} . / 100 \mathrm{ml}$.); phosphate $13.7 \mathrm{mg} . /$ $100 \mathrm{ml}$. Both serum magnesium and serum calcium were estimated with atomic absorption spectrophotometry (Unicam SP 90). Urine examination showed the presence of numerous pus cells with albumin. Urine culture grew Escherichia coli. Glucose tolerance was mildly diabetic-104 mg. $/ 100 \mathrm{ml}$. (zero hour), $106 \mathrm{mg} . / 100 \mathrm{ml}$.

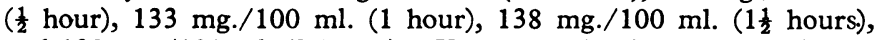
and $138 \mathrm{mg} . / 100 \mathrm{ml}$. ( 2 hours). $X$-ray examination of the abdomen showed vesical calculi and a calcified opacity in the left flank. No filling defects in the right renal pelvis were observed on retrograde pyelography, but stones were seen in the upper and lower calices of the left kidney. Chest $x$-ray examination showed a large heart with left ventricular enlargement and unfolding of aorta. Skull $x$-ray examination showed the presence of a large pituitary fossa and bony changes of acromegaly. Hand $x$-ray examination revealed typical acromegalic features-increase in length of fingers, accentua- 
tion of all the bony ridges of the phalanges and metacarpals, prominent ungual tufts, and widened joint space.

The course of the patient's illness while in hospital is presented in Fig. 1. He was given blood transfusion and appropriate antibiotics for the urinary tract infection, and he was put on a 18-g. protein modified Giovanetti diet (Shaw et al., 1965), being maintained in a reasonably steady state. On the 19th hospital day serum $\mathrm{K}$ was in the region of $6 \mathrm{mEq} / \mathrm{l}$. in spite of oral Resonium-A 15 g. q.d.s. Blood urea remained high at $281 \mathrm{mg} . / 100 \mathrm{ml}$. Peritoneal dialysis was started. A total of 57 exchanges spread over three days were carried out. Potassium was brought down to $4 \mathrm{mEq} / \mathrm{l}$. and blood urea to $75 \mathrm{mg}$. $/ 100 \mathrm{ml}$.

Immediately after dialysis there was a period of oliguria lasting for 10 days. Towards the end of this period he became confused, drowsy, and dysarthric; all tendon jerks were depressed and both knee and ankle jerks could not be elicited; limbs were all flaccid. He was afebrile. B.P. was $100 / 50$. E.C.G. (Fig. 2) showed prolonged $\mathrm{P}-\mathrm{R}, \mathrm{QRS}$, and $\mathrm{Q}-\mathrm{T}$. Serum magnesium was $4.7 \mathrm{mEq} / \mathrm{l}$. ; $\mathrm{K} 3.8 \mathrm{mEq} / \mathrm{l}$. ; $\mathrm{Na} 127 \mathrm{mEq} / \mathrm{l}$. ; Cl $87 \mathrm{mEq} / 1$. ; Ca $8.5 \mathrm{mg}$./ $100 \mathrm{ml}$.; phosphate $8.2 \mathrm{mg} . / 100 \mathrm{ml}$. ; blood urea $189 \mathrm{mg} . / 100 \mathrm{ml}$. It was thought that hypermagnesaemia was responsible for the deterioration, and intravenous $10 \%$ calcium gluconate, $20 \mathrm{ml}$. statim and $10 \mathrm{ml}$. eight-hourly, was given. Within 24 hours his mental state improved, and by 48 hours he was fully conscious, rational, and orientated. Speech was normal and blood pressure $130 / 70$. At this point the serum magnesium remained high at $4.7 \mathrm{mEq} / \mathrm{l}$., $\mathrm{K}$ was $3.9 \mathrm{mEq} / 1$., Ca $7.8 \mathrm{mg}$. $/ 100 \mathrm{ml}$., and blood urea $222 \mathrm{mg} . / 100 \mathrm{ml}$. The normal mental state persisted throughout his stay in hospital, but the tendon reflexes did not recover even when serum magnesium had finally dropped to the initial level (though still hypermagnesaemic). Oral calcium and vitamin D replaced intravenous calcium gluconate after one week. Intravenous calcium gluconate injections were given in addition whenever the serum calcium level became excessively low.

Two days after the cessation of mental change, urine output gradually improved to an average of 800 to $900 \mathrm{ml}$./day. Serum magnesium gradually came down to $2.9 \mathrm{mEq} / \mathrm{l}$. A muscle specimen was taken from the vastus lateralis for magnesium estimation at

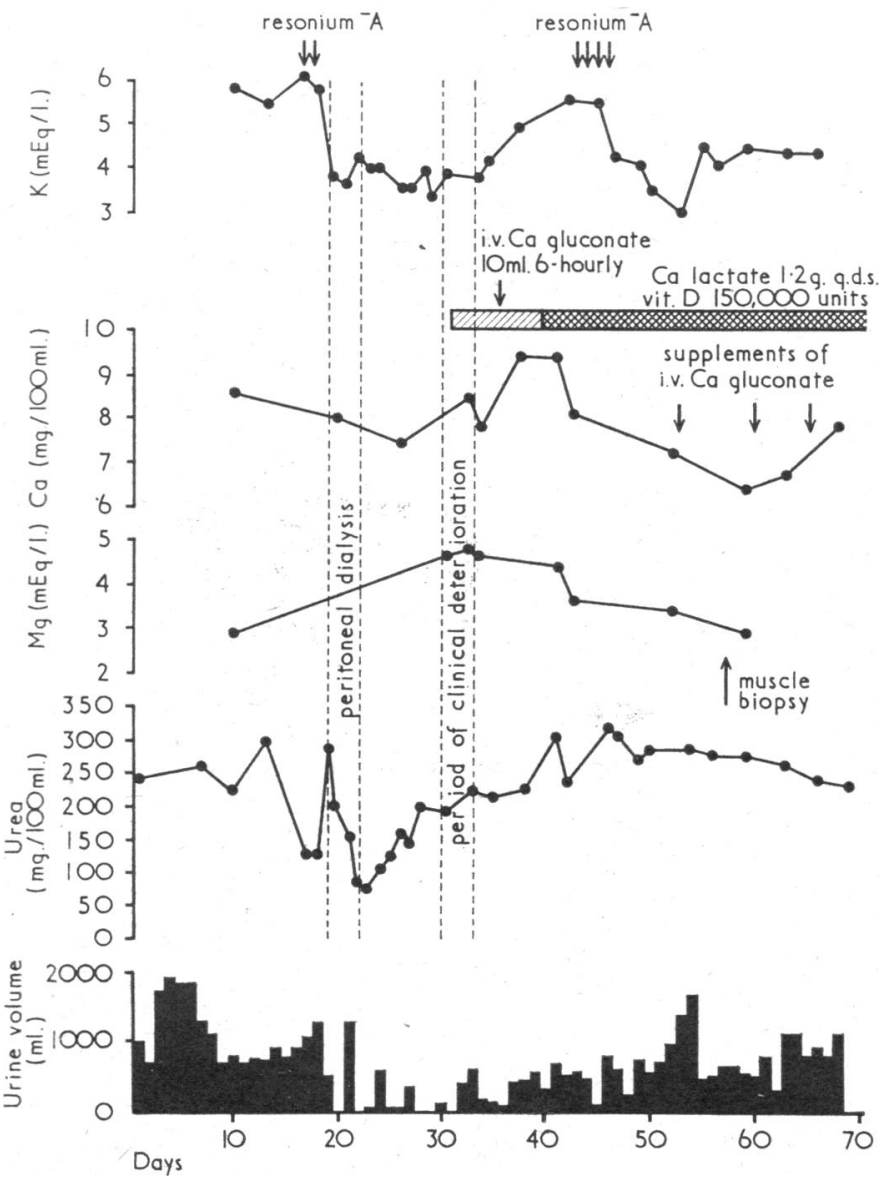

Fig. 1.-Summary of patient's course in hospital. the time when serum magnesium was at about $3 \mathrm{mEq} / \mathrm{l}$. The result was $31 \mathrm{mEq} / \mathrm{kg}$. dry fat-free solids (normal $70 \cdot 8 \pm 5 \cdot 7$ (S.D.) with the method of MacIntyre and Davidsson, 1958). The patient refused further follow-up muscle biopsies and took his own discharge on the 74th hospital day.

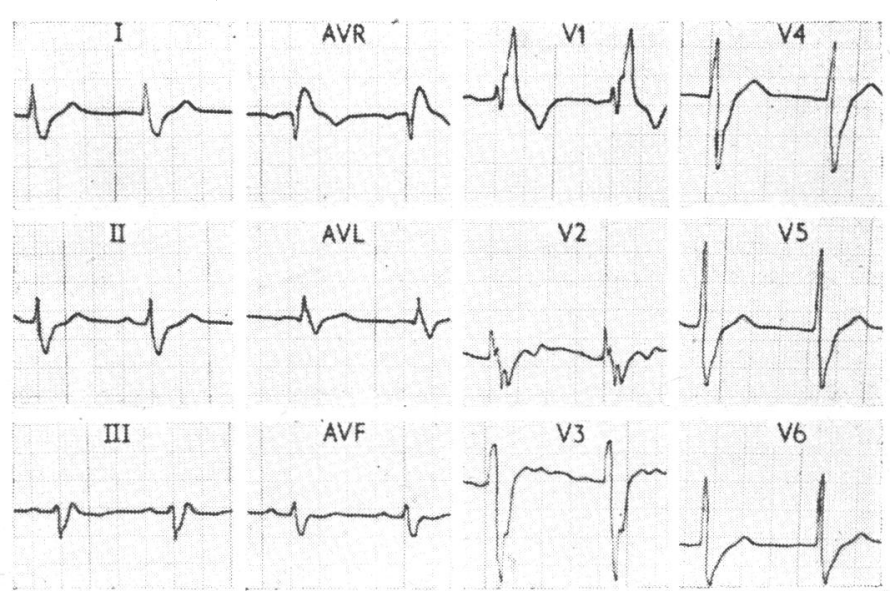

FIG. 2.-Electrocardiogram during period of clinical exacerbation.

\section{Comment}

This case shows that very high serum magnesium levels are possible in acute renal insufficiency, in the absence of a high intake of magnesium. The 18-g. protein diet, a modified Giovanetti diet (Shaw et al., 1965) aiming to provide the daily requirements of the essential amino-acids, supplied only about $150 \mathrm{mg}$. of magnesium per day. Seelig (1964) found that in a normal person a magnesium intake of at least $6 \mathrm{mg} . / \mathrm{kg}$. body weight is required to maintain metabolic balance. On this reckoning, our patient would have required about $400 \mathrm{mg}$. of magnesium per day, but with his renal function severely and progressively impaired it was not easy to know the optimal intake for him.

Estimation of the magnesium content of skeletal muscle has been found to be a reliable means of detecting magnesium deficiency (MacIntyre and Davidsson, 1958; MacIntyre et al., 1961). The normal range for man, using five samples according to MacIntyre et al. (1961), was between 63 and $78 \mathrm{mEq} / \mathrm{kg}$. dry fat-free solids. A survey has been conducted (to be published) of normal human muscle magnesium content, and the figure obtained was $70.8 \pm 5 \cdot 7$ (S.D.) $\mathrm{mEq} / \mathrm{kg}$. dry fat-free solids, using 30 specimens. Our patient's value of $31 \mathrm{mEq} / \mathrm{kg}$. dry fat-free solids pointed to a state of significant magnesium depletion. Though the biopsy was not done at the peak of hypermagnesaemia, owing to difficulty in getting the patient's consent, the serum level of magnesium at the time of biopsy was at an unequivocally hypermagnesaemic level $(3 \mathrm{mEq} / 1$.$) .$ This simultaneous occurrence of hypermagnesaemia and magnesium depletion has not been reported previously.

The non-osseous tissues, the main source of magnesium available to the extracellular fluid (MacIntyre, 1963), contain about $1,000 \mathrm{mEq}$ of $\mathrm{Mg}$, while the extracellular fluid contains only about $30 \mathrm{mEq}$ of $\mathrm{Mg}$ in an adult human. A shift to the extracellular space of only a very small fraction of intracellular $\mathrm{Mg}$ could lead to a marked increase in extracellular fluid concentration. In any case the presence of hypermagnesaemia in the face of intracellular depletion indicates some derangement in the cell membrane metabolic process concerned with maintaining the intracellular: extracellular concentration gradient of 20 to 1 . Changes in cellular hydration can, of course, alter the intracellular magnesium concentration, given the same magnesium content of the cells, and modify the gradient. This, however, cannot be the whole answer, as, assuming a normal muscle $\mathrm{Mg}$ content, the cellular water content would have to 
be doubled to bring the intracellular magnesium concentration down to the patient's figure (a little less than half the normal). The reason for the loss of the ability to maintain the normal concentration gradient across the cell wall is far from clear at the moment.

The rapid response of the mental changes to calcium is worth noting. Magnesium has a depressant action on the central and peripheral nervous system (Engbaek, 1952) and diminishes the amount of acetylcholine liberated at the neuromuscular junction (del Castillo and Engbaek, 1954). Calcium is known to antagonize these actions (Hutter and Kostial, 1954; Jenkinson, 1957). The response to calcium in the face of maintained hypermagnesaemia is in keeping with this antagonistic action of calcium. It is interesting, however, to note that the tendon reflexes were not restored with calcium therapy.

Although this patient was quite severely depleted of magnesium, probably for a considerable duration, he showed none of the outstanding clinical features of such depletion. In this particular situation it would appear that it was hypermagnesaemia and not the concomitant magnesium depletion which dominated the clinical picture.
We thank Dr. E. Jacob and the staff of the biochemistry department, Outram Road General Hospital, Singapore, for the biochemical estimations,

\section{REFERENCES}

del Castillo, J., and Engbaek, L. (1954). 7. Physiol. (Lond.), 124, 370. Engbaek, L. (1952). Pharmacol. Rev., 4, 396.

Hamburger, J. (1957). Clin. Chem., 3, 332

Hutter, O. F., and Kostial, K. (1954). F. Physiol. (Lond.), 124, 234

Jenkinson, D. H. (1957). F. Physiol. (Lond.), 138, 434.

MacIntyre, I. (1963). Sci. Basis Med., p. 218

Macintyre, 1. (1963). Sci. Basis Med., p. Riochem. 7., 70, 456.

MacIntyre, I. Hanna, S, Booth, C. C., and Read, A. E. (1961). Clin. Sci. 20, 297

Martin, H. E., and Jones, R. (1961). Amer. Heart f., 62, 206.

Nabarro, J. D. N., Spencer, A. G., and Stowers, J. M. (1952). Quart. 7. Med., 21, 225 .

Randall, R. E., jun., Cohen, M. D., Spray, C. C., jun., and Rossmeisl, E. C. (1964). Ann. intern. Med., 61, 73.

Robinson, R. R., Murdaugh, H. V., jun., and Peschel, E. (1959). F. Lab. clin. Med., 53, 572.

Seelig, M. S. (1964). Amer. f. clin. Nutr., 14, 342.

Shaw, A. B., Bazzard, F. J., Booth, E. M., Nilwarangkur, S., and Berlyne G. M (1965), Quart. 7. Med, 34, 237.

Smith, W. O., and Hammarsten, J. F. (1958). Arch. intern. Med., 102, 5 .

Takayasu, H., Sato, S., Yanadori, H., and Hirata, T. (1962). Acta med. biol. (Niigata), 10, 117.

\title{
Cutaneous Anthrax-the Non-industrial Hazard
}

\author{
A. H. KNIGHT,* M.B., B.S., M.R.C.P. ; C. J. E. WYNNE-WILLIAMS, † M.B., D.C.H., D.oBST.R.C.o.G.
}

A. T. WILLIS, $\ddagger$ M.D., PH.D., M.R.A.C.P.

Brit. med. F., 1969, 1, 416-418

Summary: Two patients contracted cutaneous anthrax $\checkmark$ after contact with infected bone meal. Awareness of the risk of infection from this source may help in achieving early clinical diagnosis and a low fatality rate following effective antibiotic therapy.

\section{Introduction}

Anthrax is an uncommon disease in the United Kingdom, yet bone-meal is widely used as a horticulture fertilizer. Two cases are presented, apparently not connected in any way, but occurring within 16 miles $(25 \mathrm{~km}$.) and nine days of each other. As neither patient works in an occupation known to carry an anthrax hazard, they show the possibility of infection in the general population.

\section{Case 1}

A 55-year-old builder was admitted to the isolation ward at Stoke Mandeville Hospital on 15 February 1968 with a swollen right elbow. Four days previously, while at work, he vaguely remembered being pricked through his jacket, and a swelling had developed at the site of the puncture. It had progressed rapidly, and on the day of admission he was febrile (temperature $102.2^{\circ} \mathrm{F} . ; 39^{\circ} \mathrm{C}$.) and toxic, with brawny oedema of the entire upper limb and a "malignant pustule" on the lateral aspect of the elbow (Fig. 1) discharging a brownish exudate. There were tender, enlarged lymph nodes in the right axilla.

* Medical Registrar, Luton and Dunstable Hospital, Luton. Present address: Royal Free Hospital, North-west Branch, Lawn Road, London N.W.3.

+ Medical Registrar, Stoke Mandeville Hospital, Aylesbury.

¥ Director, Public Health Laboratory, Luton.
About six weeks before admission he had scattered $2 \mathrm{lb} .(0.9 \mathrm{~kg}$.) of bone-meal on his chrysanthemum plot while he was wearing the same jacket. Knowing the risk to his health, he had in fact worn rubber gloves for handling the meal.

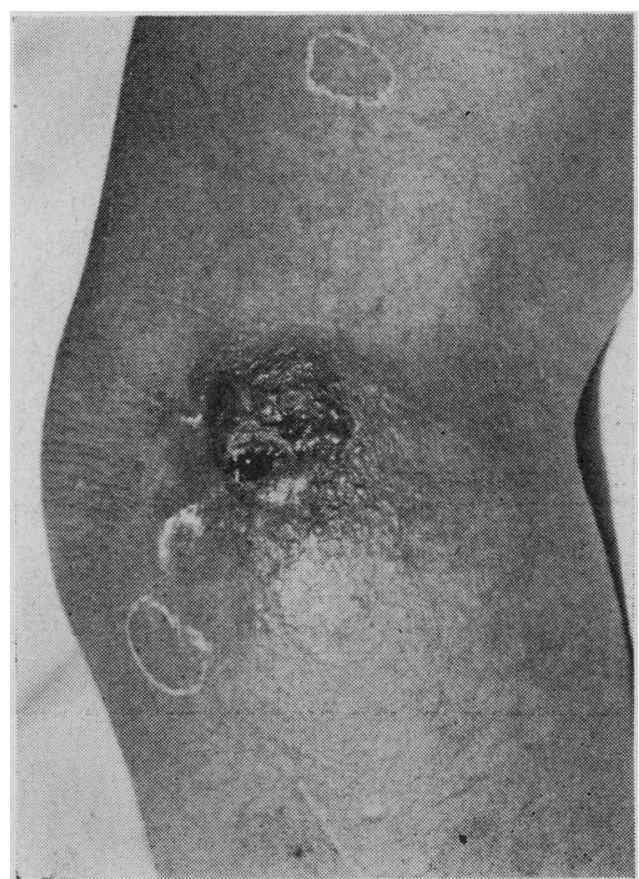

FIG. 1.-Case 1. Malignant pustule.

There was a purulent exudate from the pustule. Microscopical examination showed that it contained cellular debris and scanty but easily recognizable Gram-positive bacilli. Culture grew the typical 